\title{
Virus antibodies in systemic lupus erythematosus and other connective tissue diseases
}

\author{
PAUL E. PHILLIPS AND CHARLES L. CHRISTIAN \\ Department of Rheumatic Disease, Hospital for Special Surgery-Philip D. Wilson Research Foundation \\ affiliated with The New York Hospital-Cornell University Medical College, and Department of Medicine, \\ Cornell University Medical College, New York, N.Y. 10021, U.S.A.
}

The discovery of multitubular 'virus-like' inclusions in renal tissue from patients with systemic lupus erythematosus (SLE) (Györkey, Sinkovics, Min, and Györkey, 1972) renewed interest in the hypothesis that this and other connective tissue diseases (CTD) might have a microbial aetiology (Christian, Phillips, and Williams, 1971; Ziff, 1971). Attempts to isolate viruses from SLE have been unsuccessful (Feorino, Hierholzer, and Norton, 1970; Phillips, 1971), but increased antibodies to various viruses have been found (Phillips and Christian, 1970; Hollinger, Sharp, Lidsky, and Rawls, 1971; Hurd, Dowdle, Casey, and Ziff, 1972; Evans, Rothfield, and Niederman, 1971; Kalliomäki and Halonen, 1972). These studies failed to implicate a specific virus as the cause of SLE, but the reason for the antibody elevations was not clear. We found a direct relationship between measles and gamma globulin levels which suggested that the elevated antibody levels in SLE were due to hyperimmunoglobulinaemia (Phillips and Christian, 1972). We report here an analysis of measles, parainfluenza type 1 (Para-1), and adenovirus antibodies in relation to various clinical and laboratory parameters in subjects with SLE, other CTD and other diseases.

\section{Subjects and methods}

SLE patients had typical multiple system involvement with positive antinuclear antibody and/or lupus erythematosus (LE) cell tests. More than 85 per cent. of the rheumatoid arthritis (RA) patients had classical or definite disease (Ropes, Bennett, Cobb, Jacox, and Jessar, 1959). The diagnosis of juvenile rheumatoid arthritis (JRA) was certain in two-thirds of this group. One-third of the other CTD group had scleroderma and one third vasculitis (systemic and dermal); the remaining patients included five with mixed CTD syndromes, two with dermatomyositis, and three with drug-induced LE. All except three patients in the Reiter's syndrome group had the complete triad of arthritis, urethritis, and conjunctivitis. One-quarter of the patients in the miscellaneous diseases (non-CTD) group had arthritides not due to CTD (e.g. gout, osteoarthritis); $\mathcal{D}$ ten each had neoplastic and neurological disorders. Seven 0 each had cardiopulmonary and infectious diseases, six had gastrointestinal and liver disorders, and the remainder diseases of other systems. The normal group was hospital $\stackrel{\Phi}{-}$ personnel. Dr. Y. Hirshaut kindly provided sera frog blood bank donors and patients with sarcoidosis.

Sera were stored at $-20^{\circ} \mathrm{C}$. and coded before testing Standard micromethods were used for measuring measfes and Para-1 haemagglutination-inhibition (HI) antibodies (Phillips and Christian, 1970), and, in heated $\left(56^{\circ} \mathrm{C}\right.$; $30 \mathrm{~min}$.) sera, complement-fixation (CF) antibody against adenovirus group antigen (Casey, 1965). All virus and control antigens (fluids from uninoculated tissue cultures of the same type used to make the virus antigens) were obtained commercially (Microbiological Associates, Bethesda, Md.). Antibody titres were expressed as the $\log _{2}$ reciprocal of the highest 2 -fold serum dilution showing $\mathrm{HI}$ or CF. Serum immunoglobulin concentration was measured in duplicate by radial immunodiffusion (Mancini, Carbonara and Heremans, 1965). Appropriate controls were included in all tests. In sequential studies of a single subject, all sera were done in the same test.

Clinical parameters analysed in relation to virus antibody levels included age, sex, race, duration of disease, and treatment with, and dose of, prednisone or azathioprine. Hospital laboratory tests analysed were gamma globulin $\frac{7}{0}$ (cellulose acetate electrophoresis), antinuclear antibody, LE cells, latex-fixation, and complement. Standard statis- N tical methods were used for the $t$ test, Pearson correlation coefficient, and $\chi^{2}$ test (Croxton, 1959).

Two normal and two SLE sera were absorbed with $\underset{\omega}{N}$ various reagents to determine the specificity of the $O$ measles and Para-1 HI antibody reactions. The absorbants were salmon sperm DNA (Worthington) and yeast RNA (Mann), each at $3.78 \mathrm{mg} . / \mathrm{ml}$. serum; purified rheumatoid factor (latex-fixation titre $>1: 10000$ ) at $5.6 \mathrm{ml} . / \mathrm{ml}$. serum; ? washed sonicated KB tissue culture cells at $0.5 \mathrm{ml}$. packed cell volume $/ \mathrm{ml}$. serum; adenovirus group CF antigen at $9.5 \mathrm{ml} . / \mathrm{ml}$. serum; and measles CF and Para-1 haemag- 
glutinating virus and control antigens concentrated by ultracentrifugation. Calculated from the haemagglutinating activity of the concentrated virus antigens, the equivalent volume of unconcentrated measles antigens used for absorption was $72 \mathrm{ml} . / \mathrm{ml}$. serum, and of Para-1 antigens $18 \mathrm{ml} . / \mathrm{ml}$. The control had normal saline added; final dilution of the serum aliquots was identical after addition of each absorbant. The mixtures were incubated $\left(37^{\circ} \mathrm{C}\right.$.; $1 \mathrm{hr}$ ), centrifuged and the supernatants saved for antibody testing.

\section{Results}

The mean virus antibody titres of the SLE group were generally significantly higher than the other groups (Table I). This elevation was most marked for measles, and least for adenovirus. The only other significant findings were higher Para-1 antibody in the small Reiter's syndrome group, and the apparent absence of adenovirus antibody in RA.

A significant direct correlation was found between measles antibody and gamma globulin levels in SLE $(P<0.01)$, non-SLE $(P<0.001)$, and the combined groups $(P<0.001)$. IgG levels were also determined in 72 of these subjects and again a significant direct correlation with measles antibody was found $(P<0.02)$. Similarly, when IgG and measles antibody levels were measured in a new group of non-SLE subjects, a significant correlation was found (Fig. 1). Analysis of the other clinical and laboratory parameters revealed only that Negroes generally had higher measles antibody and immunoglobulin levels than whites.

A significant positive correlation was also found between Para-1 antibody and gamma globulin levels in the 67 patients (SLE and other diseases) with both tests $(P<0 \cdot 05)$. Para-1 and measles antibody levels also correlated significantly in 147 subjects (SLE and other diseases) $(P<0.02)$. Para-1 antibody showed a significant tendency to decline with disease duration and/or age in some groups. Significant relationships to other parameters were not found.

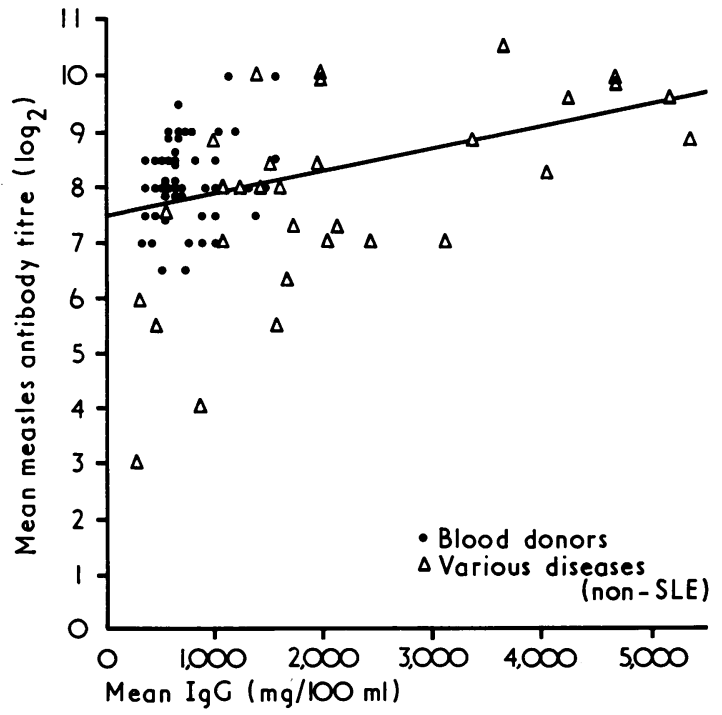

F IG. 1 Scatter plot of measles antibody titre and IgG levels in 49 blood donors and 31 subjects with diseases other than SLE. Regression line: $y=7.5231+0.000382 x ; r 0.35 ; P$ $<0.005$

A significant inverse correlation was found between age and adenovirus antibody for both the SLE group $(P<0.01)$ and the whole population $(P<0.001)$. No other significant relationships were found with the other parameters, or with measles or Para-1 antibodies.

IgG and measles antibody were determined in up to twelve sequential sera, spanning periods of 1 wk to 75 mths (mean $17.6 \mathrm{mths}$ ) from each of 33 subjects (7 SLE, 24 other diseases, 2 normal). Generally, excellent correspondence was found between changes in IgG and changes in measles antibody in patients with SLE (Figs 2 and 3). Fourfold or greater changes in measles antibody were seen seven times (e.g. Figs 2A, 2B). In normal subjects and diseases other than SLE there was also good correspondence between changes in IgG and measles antibody (Fig. 4); a

Table I Geometric mean titres ( $\left.\log _{2}\right)$ of measles, parainfluenza type 1, and adenovirus antibodies in SLE, various $C T D$, and controls

\begin{tabular}{|c|c|c|c|c|}
\hline Group & Measles (n) & Parainfluenza (n) & Aden & ovirus $(n)$ \\
\hline $\begin{array}{l}\text { SLE } \\
\text { RA } \\
\text { JRA } \\
\text { Other CTD } \\
\text { Reiter's } \\
\text { Non-CTD } \\
\text { Normal } \\
\text { All Non-SLE }\end{array}$ & $\begin{array}{lr}6 \cdot 2 * & (68) \\
5 \cdot 0 & (26) \\
3 \cdot 6 & (9) \\
4 \cdot 6 & (31) \\
5 \cdot 3 & (11) \\
4 \cdot 7 & (73) \\
4 \cdot 5 & (20) \\
4 \cdot 7 & (170)\end{array}$ & $\begin{array}{ll}8.5 \dagger & (40) \\
7.7 & (20) \\
7.5 & (9) \\
7.6 & (21) \\
8.58 & (6) \\
7.9 & (32) \\
7.0 & (20) \\
7.6 & (108)\end{array}$ & $\begin{array}{l}1 \cdot 6 \ddagger \\
0\|\| \\
0 \cdot 6 \\
0 \cdot 5 \\
0 \cdot 4 \\
1 \cdot 1 \\
1 \cdot 0 \\
0.8\end{array}$ & $\begin{array}{l}(35) \\
(17) \\
(7) \\
(17) \\
(5) \\
(24) \\
(20) \\
(73) \Phi\end{array}$ \\
\hline
\end{tabular}

* Significantly higher than all other groups except Reiter's, $\mathrm{P}<0.02$ or less.

+ Significantly higher than all other groups except Reiter's and non-CTD, $P<0.025$ or less.

\$ Significantly higher than RA, other CTD, all non-SLE, $P<0.05$ or less.

Significantly higher than normals, $P<0.02$.

II Significantly lower than all groups except JRA and Reiter's, $P<0.05$ or less.

II Excluding RA. 


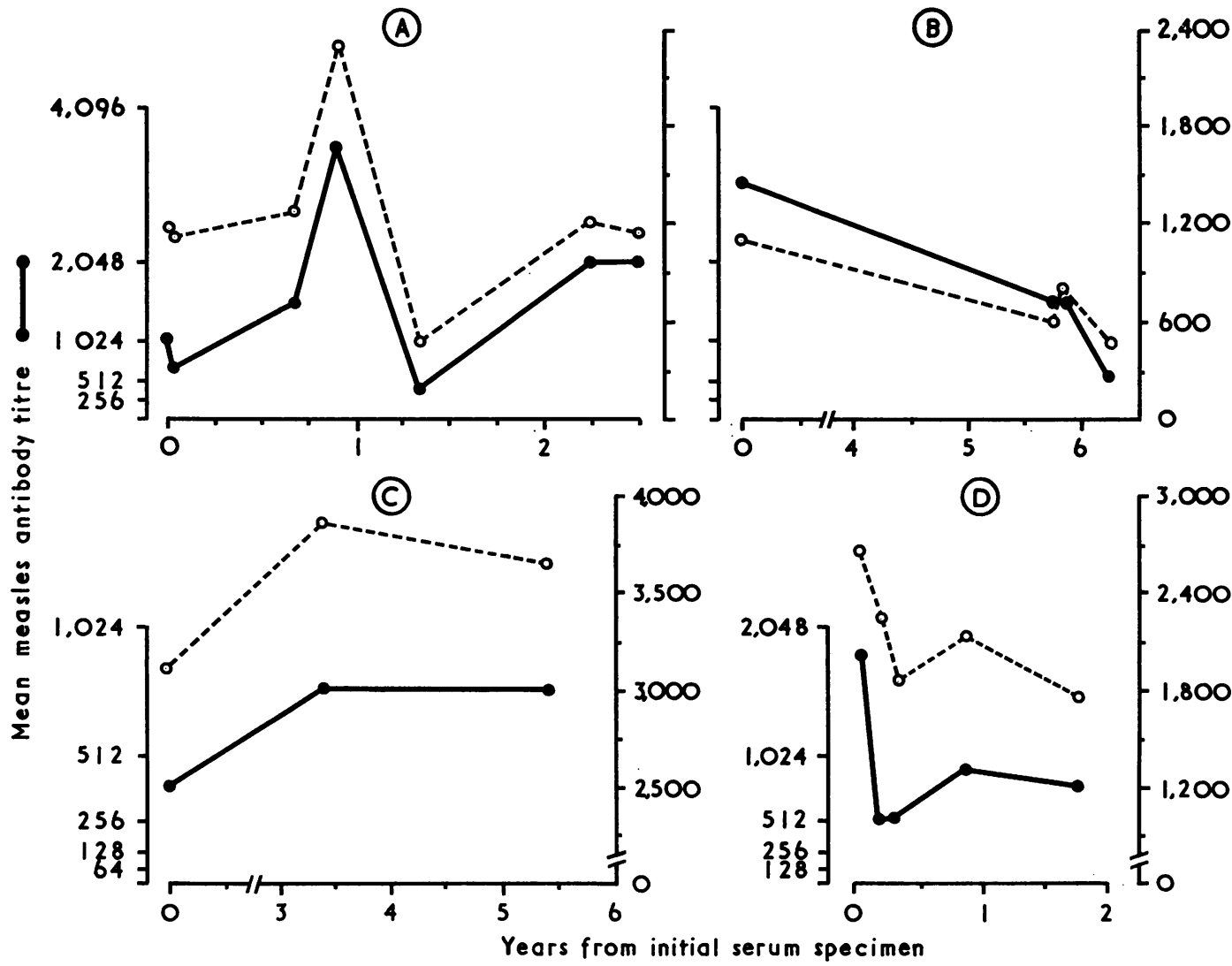

FIG. 2 Corresponding changes in sequential measles antibody titres and IgG levels in four patients with SLE

A. 13-year-old white girl with two significant increases in measles antibody: from second to fourth and from fifth to sixth serum

B. 30-year-old Negro woman with significant decrease in measles antibody from first to fourth serum

C. 35-year-old Negro woman

D. 27-year-old Puerto Rican man

Table II Correspondence between changes in IgG and measles antibody levels in sequential sera from 33 subjects

\begin{tabular}{|c|c|c|c|c|c|}
\hline \multirow[t]{2}{*}{ Group } & \multirow[t]{2}{*}{ No. of cases } & \multicolumn{2}{|c|}{$\begin{array}{l}\text { Changes in sequential IgG and measles antibody } \\
\text { levels }{ }^{*}\end{array}$} & \multicolumn{2}{|c|}{ Significance $\dagger$} \\
\hline & & No. concordant/total & Per cent. concordant & $\chi^{2}$ & $P$ \\
\hline $\begin{array}{l}\text { SLE } \\
\text { Non-SLE } \ddagger \\
\text { Total }\end{array}$ & $\begin{array}{r}7 \\
26 \\
33\end{array}$ & $\begin{array}{l}32 / 39 \\
31 / 46 \\
63 / 85\end{array}$ & $\begin{array}{l}82 \\
67 \\
74\end{array}$ & $\begin{array}{r}16 \cdot 1 \\
5 \cdot 6 \\
19 \cdot 8\end{array}$ & $\begin{array}{l}<0.001 \\
<0.02 \\
<0.001\end{array}$ \\
\hline
\end{tabular}

* Concordant change in measles antibody and IgG levels was in the same direction or, if no change in one variable, $\leqslant 10$ per cent. change in the $N$

other; discordant change was in opposite directions or, if no change in one, $>10$ per cent. change in the other.
$\dagger \chi^{2}$ with Yate's correction was determined for each group by comparing the observed frequency of concordant and discordant changes with the $\sigma$ equal frequency expected if changes in IgG and measles antibody levels were randomly distributed.

$\ddagger 24$ diseases other than SLE, two normal subjects.

significant change in measles antibody was found once (Fig. 4A). Table II summarizes the correspondence between changes in IgG and measles antibody. Corresponding changes were significantly greater than expected on a random basis in both the SLE and nonSLE groups. Sequential IgM levels were measured in three of the SLE patients. Changes in IgM generally $\stackrel{?}{?}$ corresponded with changes in IgG, and in measles antibody (Fig. 3).

Sequential Para-1 antibody levels were studied in 31 of these subjects. Correspondence between changes $\stackrel{\square}{\varrho}$ in Para-1 antibody and IgG was fair in both the SLEO 


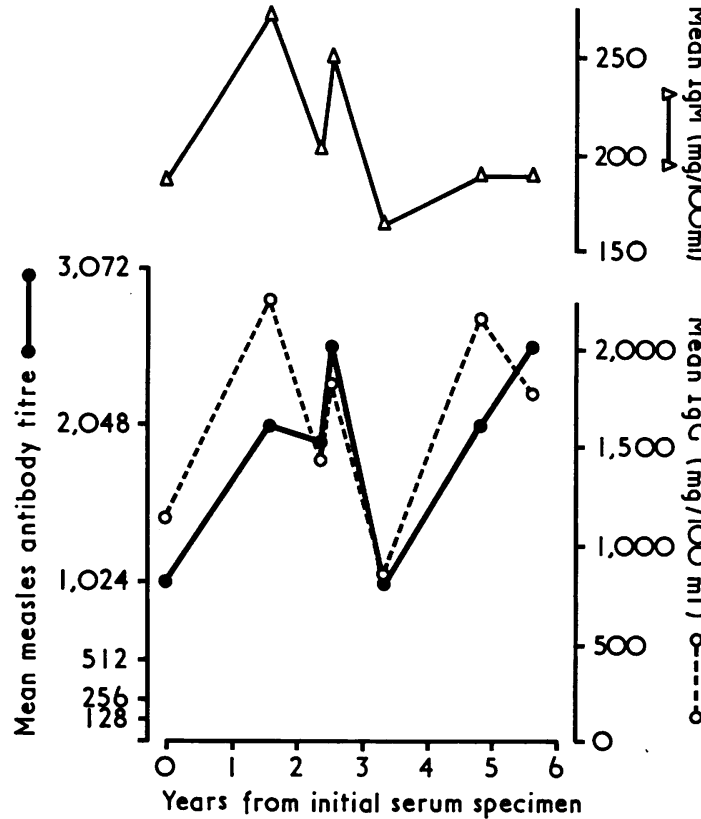

FIG. 3 Corresponding changes in sequential measles antibody titres and IgG levels in a 44-year-old Negro woman with SLE. Changes in IgM level are similar to those in IgG

and non-SLE subjects; in both groups combined it was 59 per cent., which was not significant. Significant changes in Para-1 antibody were found in only two patients; these were concordant with changes in IgG in one patient, but discordant in the other.

Nine subjects were studied for changes in adenovirus antibody over periods of 2 wks to $65 \mathrm{mths}$; two of five SLE patients had 4-fold or greater changes. Changes in IgG were concordant in one and discordant in the other. The remaining four subjects (non-SLE) had no significant changes; IgG was stable in the one subject tested.

In eight subjects (6 SLE, 2 normal), sequential antibody levels against both native and denatured DNA were kindly performed by Dr. David Koffler using the haemagglutination technique (Koffler, Carr, Agnello, Thoburn, and Kunkel 1971). Antibody against native DNA was present in four SLE patients, three of whom also had anti-denatured DNA antibody. No significant correspondence was found between changes in anti-DNA antibody and either IgG or measles antibody. Nor was any consistent relationship found between changes in virus antibody levels and clinical activity, dose of corticosteroid, or serum complement level in these SLE patients.

The effect of absorption with measles and Para-1 virus and control antigens on measles antibody titres of two SLE and two normal sera is shown in Fig. 5 (top). Compared to the saline control, measles antigen absorbed homologous antibody completely out of all four sera, while control antigen had a negligible effect.

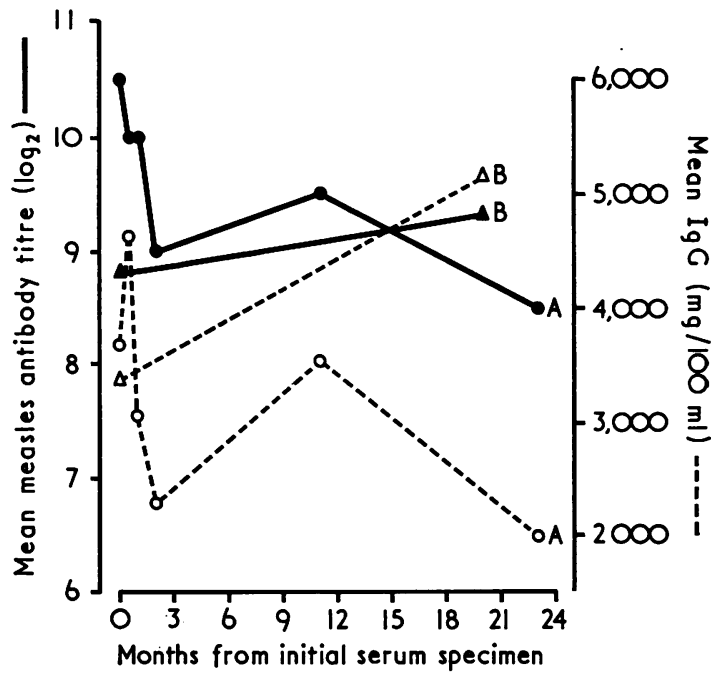

FIG. 4 Corresponding changes in measles antibody titres and IgG levels in:

A. 7-year-old negro girl with juvenile rheumatoid arthritis, with a significant decrease in measles antibody titres from first to sixth serum

B. Patient with sarcoidosis

Absorption with Para-1 antigen resulted in small increases in measles antibody titre, while its control antigen had little effect. For Para-1 antibody (Fig. 5, bottom), absorption with homologous virus antigen resulted in small decreases in antibody titre. Absorption with control Para-1 antigen resulted in little change, but both measles and its control antigens gave 2 to $3 \log _{2}$ increases in three sera. No significant decreases in either measles or Para-1 antibody titres were seen after absorption with DNA, RNA, or the other reagents.

\section{Discussion}

Numerous investigators have found varying elevations of many virus antibodies in SLE (Phillips and Christian, 1970; Hollinger and others, 1971; Hurd and others, 1972; Evans and others, 1971 ; Kalliomäki and Halonen, 1972; Stevens, Stevens, Newell, Levine, and Waggoner, 1972; Phillips and Hirshaut, 1973). Factors contributing to the different results from different laboratories include size and composition of the SLE and control populations and sensitivity of the methods for measuring virus antibodies. The overall picture in SLE is one of small to moderate, although frequently significant, increases of antibodies to many viruses, both RNA and DNA, which belong to a variety of taxonomic groups. This might be nonspecific, and our absorption studies were done to exclude the possibility that autoantibodies in SLE sera would react with the measles or Para-1 antigens. Had this occurred, absorption with antigens appro- 


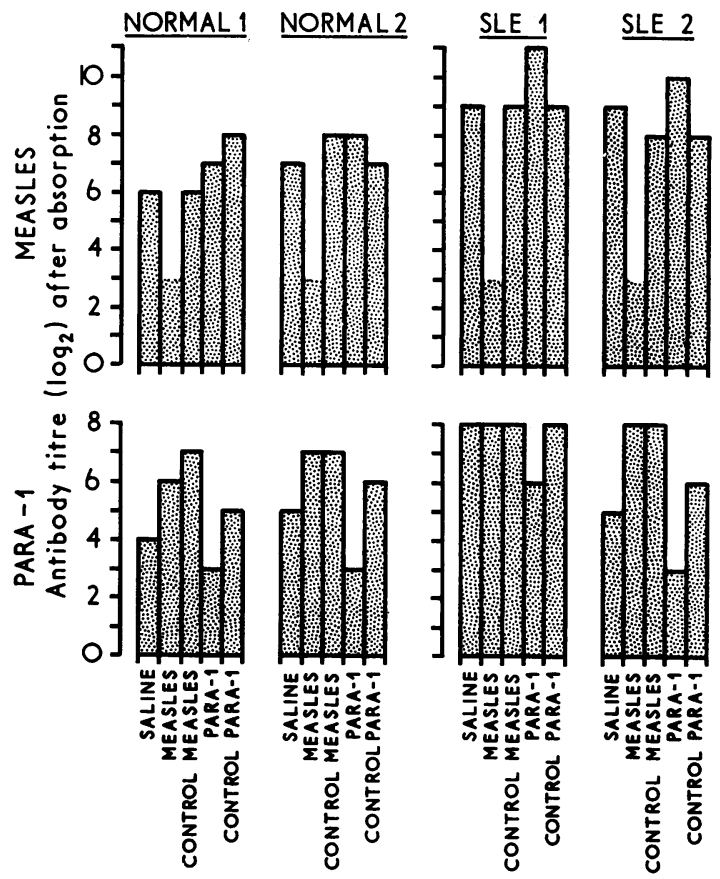

FIG. 5 Absorption studies of measles (top) and Para-1 (bottom) antibodies in two normal and two SLE sera (openended bars indicate antibody absent at that dilution, the lowest tested; see text for explanation)

priate for the autoantibodies would decrease the virus antibody titre in comparison to the unabsorbed control. This was not observed except after absorption with homologous virus antigen, nor was there a significant difference between the behaviour of SLE and normal sera. The lack of correspondence between changes in anti-DNA and virus antibody levels in the sequentially studied patients provides further confirmation that autoantibodies are not responsible for the elevated measles and Para-1 antibodies in SLE, a conclusion reached by Hollinger and others (1971) also.

In an effort to clarify the cause of virus antibody elevations in SLE, their relationship to clinical and laboratory data was examined in this study. The only significant direct correlations found were with gamma globulin or IgG levels for measles antibody and, less so, for Para-1 antibody. These correlations were relatively loose: a subject's virus antibody level could not be predicted from his immunoglobulin level ( $c f$. Fig. 1). Likewise, in sequentially studied subjects, correspondence between changes in IgG and virus antibodies was better for measles than for Para-1, and was usually qualitative rather than quantitative. This indicates that immunoglobulin level is only one of several determinants of measles and Para- 1 antibody levels. Age is one such determinant of virus antibody levels (which tend to decline with increasing age and remoteness of primary infection); this was clearly shown in this study only for adenovirus anti-
body.

The 4-fold or greater changes in virus antibody levels in the sequentially studied subjects would $\stackrel{5}{?}$ usually be interpreted as evidence of recent infection? or re-infection with that virus. This could not be excluded retrospectively, but the occurrence of two such changes in measles antibody in each of three $\stackrel{\mathbb{Q}}{2}$ subjects makes measles re-infection (rare at best) an unlikely cause. Re-infection would not in any case $\vec{\circ}$ explain the often large corresponding changes in IgG. Thus, it seems most likely that the changes in measles $\vec{\omega}$ antibody found in our patients resulted from changes in their IgG levels and that such changes should not necessarily be interpreted as evidence of virus infec- $\omega$ tion or re-infection (Phillips and Christian, 1972). or

The reason for the small to moderate virus antibody of elevations in SLE is unclear, because the mechanism 0 of persistent immunity to viruses is unknown. Since $\mathrm{O}$ their multiplicity makes it unlikely that chronic infec- tion with any one of the viruses causes the disease, $\mathbb{D}$ three other interpretations are possible. The primary $\frac{}{\Phi}$ defect in SLE allows abnormal persistence of multiple $\frac{\mathbb{1}}{3}$ viruses (or their antigens), or it allows more frequent $\bar{\varnothing}$ re-infections, or it generally stimulates the humoural ${ }_{-}^{-}$ immune system, resulting in a polyclonal hyperio munoglobulinaemia and incidentally increased virus antibodies. Current evidence favours the last intê응 pretation. Such hyperactivity of the humoural immune system is a major feature of SLE, with production of many auto-antibodies and polyclonal hyperimmunoglobulinaemia. In the animal model of SLE, $\stackrel{\mathbb{Q}}{\square}$ New Zealand mouse disease, various virus and syn- $\overrightarrow{\overrightarrow{0}}$ thetic nucleoproteins accelerate disease, suggesting 3 that these mice are immunologically hyper-responsive $\supset$ (Tonietti, Oldstone, and Dixon, 1970; Hahn, Stevens, Remington, and Shulman, 1971). Our data also favour the interpretation that moderate elevations of virus $?$ antibodies can result from polyclonal hyperimmuno- $\frac{0}{3}$ globulinaemia, in both SLE and other diseases (Phillips and Christian, 1972; Phillips and Hirshaut, 응 1973; Phillips, Lim, Parkman, and Hirshaut, 1973).

Studies of virus antibodies in RA and the other $\frac{\text { ? }}{5}$ CTD have shown few differences from controls $\frac{D}{2}$ (Waller, Sever, Curry, and Gilkeson, 1966; Smiley and Casey, 1969; Norton, Velayos, and Robison, $N$ 1970; Phillips and Christian, 1970; Kacaki, Balduzzi, and Vaughan, 1970; Hollinger and others, 1971; Hurd $\mathcal{O}$ and others, 1972; Wilkes, Simsarian, Roth, Hopps, $\mathcal{\omega}$ Decker, Aptekar, and Meyer, 1973; Chandler, Robinson, and Masi, 1971; Gordon, Pawlin, and Franklin, 1972; Stevens and others, 1972; Kalliomäki $\Phi_{\overparen{D}}$ and Halonen, 1972; Laitinen, Vesikari, and Vaheri, $\stackrel{+}{+}$ 1972; Ogra and Herd, 1972; Phillips and others, $\frac{T}{0}$ 1973). In RA, a few studies have found high or low $\frac{0}{D}$ levels of some virus antibodies, but no consistent $\stackrel{?}{Q}$

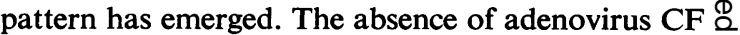
antibody in this study is probably artefactual, since 
rheumatoid factor interferes in the CF antibody test (Wilkes and others, 1973), and many of our RA patients had high titres of rheumatoid factor.

In conclusion, the striking elevation of a single virus antibody necessary to implicate that virus aetiologically has not yet been found in any CTD. However, such negative evidence does not exclude chronic virus infection as the cause of these diseases.

\section{Summary}

Measles and parainfluenza type 1 antibody levels were significantly elevated in systemic lupus erythematosus (SLE). A significant direct relationship was found between measles antibody and immunoglobulin levels in both SLE and other subjects; the two parameters also tended to rise or fall together in sequentially studied subjects. A similar, less significant relationship existed for parainfluenza type 1 antibody. Crossabsorption studies showed these virus antibody elevations did not result from nonspecifically-reacting autoantibodies. Adenovirus antibody was slightly increased in SLE, but was absent in rheumatoid arthritis. The multiple virus antibody elevations in SLE probably result from polyclonal hyperimmunoglobulinaemia, and do not implicate these viruses aetiologically.

We thank Miss R. Hargrave, Miss J. Benson, and Mrs. J. Brindisi for valuable technical assistance, Mrs. Covolo for gamma globulin determinations, and Mrs. M. Park and Dr. V. Butler, Jr., for help with statistical analysis. This study was supported by grants from the John A. Hartford Foundation and the U.S. Public Health Service (AM14627). Research Department Publication No. 420.

\section{References}

CASEY, H. L. (1965) 'Adaptation of Laboratory Branch CF method to microtechnique', in "Standardized Diagnostic Complement Fixation Method, and Adaptation to Micro Test”, Public Health Monograph No. 74, p. 31. U.S. Government Printing Office, Washington, D.C.

Chandler, R. W., Robinson, H., ANd Masi, A. T. (1971) Ann. rheum. Dis., 30, 274 (Serological investigations for evidence of an infectious etiology of rheumatoid arthritis)

Christian, C. L., Phillips, P. E., AND Williams, R. C. (eds) (1971) 'Atypical Virus Infections-Possible Relevance to Animal Models and Rheumatic Disease'. Arthritis Foundation, New York, N.Y.

CRoxton, F. E. (1959) 'Elementary Statistics with Applications in Medicine and the Biological Sciences', pp. 112, 228, 267, 312. Dover Publications, New York, N.Y.

Evans, A. S., Rothfield, N. F., AND Niederman, J. C. (1971) Lancet, 1, 167 (Raised antibody titres to EB virus in systemic lupus erythematosus)

Feorino, P. M., Hierholzer, J. C., AND Norton, W. L. (1970) Arthr. and Rheum., 13, 378 (Virus isolation studies of inclusion positive biopsy specimens from human connective tissue diseases)

Gordon, D. A., Pawlin, G., AND Franklin, A. E. (1972) in 'Immune Reactions and Experimental Models in Rheumatic Diseases, ed. D. A. Gordon, p. 112. Univ. of Toronto Press, Toronto (Microbiological antibody studies in seropositive and seronegative rheumatoid arthritis)

GyörkeY, F., Sinkovics, J. G., Min, K.W., AND GyörkeY, P. (1972) Amer. J. Med., 53, 148 (A morphologic study on the occurrence and distribution of structures resembling viral nucleocapsids in collagen diseases)

Hahn, B. H., Stevens, M. B., Remington, M., And Shulman, L. E. (1971) J. Lab. clin. Med., 77, 558 (Heightened circulating antibody responses in New Zealand mice)

Hollinger, F. B., Sharp, J. T., LidSky, M. D., AND RaWls, W. E. (1971) Arthr. and Rheum., 14, 1 (Antibodies to viral antigens in systemic lupus erythematosus)

Hurd, E. R., Dowdle, W., CASEY, H., AND ZifF, M. (1972) Ibid., 15, 267 (Virus antibody levels in systemic lupus erythematosus)

KaCAKI, J. N., Balduzzi, P. C., AND Vaughan, J. H. (1970) Clin. exp. Immunol., 6, 885 (A study of rubella haemagglutination inhibition antibodies in rheumatoid arthritis)

Kalliomaki, J. L., AND Halonen, P. (1972) Ann. rheum. Dis., 31, 192 (Antibody levels to parainfluenza, herpes simplex, varicella-zoster, cytomegalovirus and measles virus in patients with connective tissue diseases)

Koffler, D., Carr, R., Agnello, V., Thoburn, R., AND Kunkel, H. G. (1971) J. exp. Med., 134, 294 (Antibodies to polynucleotides in human sera: antigenic specificity and relation to disease)

Laitinen, O., Vesikari, T., AND VAHERI, A. (1972) Acta med. scand., 192, 37 (Virus antibody levels in rheumatoid arthritis and systemic lupus erythematosus)

Mancin, G., Carbonara, A. O., AND Heremans, J. F. (1965) Immunochemistry, 2, 235 (Immunochemical quantitation of antigens by single radial immunodiffusion)

Norton, W. L., Velayos, E., AND Robison, L. (1970) Ann. rheum. Dis., 29, 67 (Endothelial inclusions in dermatomyositis)

OGRA, P. L., AND HeRd, J. K. (1972) Arthr. and Rheum., 15, 121 (Serologic association of rubella virus infection and juvenile rheumatoid arthritis) (abst)

Phillips, P. E. (1971) J. exp. Med., 134, pt. 2, 313s (Virologic studies in rheumatoid arthritis and other connective tissue diseases)

- AND Christian, C. L. (1970) Science, 168, 982 (Myxovirus antibody increases in human connective tissue disease)

- (1972) Proc. soc. exp. biol. (N.Y.), 140, 1340 (The influence of serum immunoglobulin concentration on measles antibody level) 
- - AND HIRShAUT, Y. (1973) Arthr. and Rheum., 16, 97 (Epstein-Barr virus antibody levels in systemic lupus erythematosus)

—_, Lim, W. N., Parkman, P. D., And Hirshaut, Y. (1973) Ibid., 16, 126 (Virus antibody and IgG levels in juvenile rheumatoid arthritis) (Abst)

Ropes, M. W., Bennett, G. A., CobB, S., Jacox, R. F., and Jessar, R. A. (1959) Ann. rheum. Dis., 18, 49 (1958 revision of diagnostic criteria for rheumatoid arthritis)

Smiley, J. D., AND CASEY, H. L. (1969) Arthr. and Rheum., 12, 698 (Decreased complement-fixation antibodies in sera and decreased lymphocyte transformation to herpes simplex in patients with rheumatoid arthritis) (Abst)

Stevens, D. A., Stevens, M. B., Newell, G. R., LeVine, P. H., AND Waggoner, D. E. (1972) Arch. intern. Med., 130, 23 (Epstein-Barr virus (herpes-type virus) antibodies in connective tissue diseases)

Tonietti, G., Oldstone, M. B. A., AND Dixon, F. J. (1970) J. exp. Med., 132, 89 (The effect of induced chronic viral infections on the immunologic diseases of New Zealand mice)

Waller, M., Sever, J., Curry, N., AND Gilkeson, M. R. (1966) Ann. rheum. Dis., 25, 327 (Relationship between anti-viral antibodies and rheumatoid factor in pregnant women)

Wilkes, R. M., Simsarian, J. P., Roth, H., Hopps, H. E., Decker, J. L., Aptekar, R. G., AND Meyer, H. M., JR. (1973) Arthr. and Rheum., in press (Virologic studies on rheumatoid arthritis)

ZIFF, M. (1971) Ann. intern. Med., 75, 951 (Viruses and the connective tissue diseases) 